日臨外会誌 $61 （ 8) ， 2159-2163 ， 2000$

症例

肝動脈塞栓療法後の腫瘍栓にて総胆管閉塞を呈した肝細胞癌の 1 例

山口県立中央病院外科

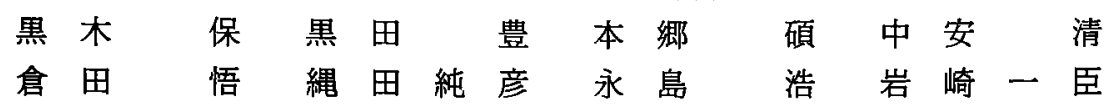

肝細胞癌に対して施行した肝動脈塞栓療法後に胆管腫瘍栓にて黄㾝を発症した 1 例を 経験したので報告する.症例は63歳女性.C 型肝炎にて経過観察中に S 8 に肝細胞癌を認 め, 2 回の肝動脈塞栓療法が施行された. その後, 右季肋部痛と黄疸にて入院となり CT 検查, 超音波検查, ERCPにて肝内胆管の㹡張, 総胆管の閉塞, 胆管に充満する腫崵栓 を認め閉塞性黄疸の診断にて手術を施行した。胆管内に充満する壊死腫湟と胆泥を認め, これらを除去し胆道再建と肝切除術を施行した。病理所見にて腫瘍栓は, ほとんどが壊 死組織で S 8 の腫瘍と同一の中分化肝細胞癌と診断された. 腫瘍栓の原因として肝動脈 塞栓療法による胆管壁の壤死・破綻が考えられた。肝動脈塞栓療法の合併症として壊死 腫場による胆管腫揚栓も念頭に置くことが必要と思われた.

索引用語：肝動脈塞栓療法, 合併症, 胆管腫瘍栓

緒言

肝細胞癌に対する肝動脈塞栓療法は肝細胞癌に対し て広く行われている. それと同時に，肝動脈塞栓療法 に伴う合併症が多数報告されている. 今回われわれは 肝細胞癌に対して施行した肝動脈塞栓療法後に胆管腫 瘍栓にて黄疸を発症した 1 例を経験した。胆管腫瘍栓 は肝動脈塞栓療法の重要な合併症の 1 つと考えられる ので報告し，その原因について考察した。

$$
\text { 症例 }
$$

患者：63歳，女性.

主訴: 右季助部痛.

既往歴：1985年よりC 型肝炎にて経過観察.

現病歴：1996年 1 月, 肝 S 4 に径 $3 \mathrm{~cm}$ の腫瘤を認め 肝細胞癌の診断.エピルビシン $80 \mathrm{mg}$ とリピオドール $5 \mathrm{ml}$, ゲルフォーム細片を用いて右肝動脈より肝動脈 塞栓療法が施行された. 1998年 7 月 AFP の上昇傾向 を認めたため肝動脈前上行枝より前回と同様の薬㓣に て肝動脈塞栓療法を施行した. 2 回目の肝動脈塞栓療 法施行時の血管造影では肝 S 8 に径 $4 \mathrm{~cm}$ の hypervascular な腫㿔像を認め, 門脈造影では門脈腫瘍塞栓 は認めなかった(図 $1 \mathbf{A}$ ). 施行後のCTではリピオド ールの良好な集積を認め, 肝内胆管・総胆管の拻張は

1999年11月22日受付．2000年 5 月 8 日採用
認められなかった(図 1 B)。1998年11月より, 右季肋 部に鈍痛を認め症状が綝り返すため1999年 1 月 7 日精 查加療目的にて入院となった。

入院時現症：眼球結膜に黄㾝を認め, 眼瞼結膜に賓 血なし. 腹部は平坦, 腫瘤は触知せず, 右季肋部に軽 度圧痛を認めた。

入院時検査所見 (表 1$)$ : 肝・胆道系醅素の上昇と, 総ビリルビン值 $3.9 \mathrm{mg} / \mathrm{dl}$ と黄疸を認めた。腫陽マー カーでは AFP が274ng $/ \mathrm{ml}$ と高値であった。

検査所見経過：肝・胆道系酵素はしだいに低下を示 した. 総ビリルビン值は 1 月 11 日には, $9.1 \mathrm{mg} / \mathrm{dl}$ と上 昇したが， 3 日後には $4.3 \mathrm{mg} / \mathrm{dl}$ と低下を認めた。

腹部超音波検査：拡張した総胆管内に充実性のエコ 一像を認めたが胆管壁は保たれていた（図2)。

\section{表 1 入院時検查所見}

\begin{tabular}{lrlrl}
\hline WBC & $6,600 / \mathrm{mm}^{3}$ & & HCV $-\mathrm{Ab}(+)$ \\
RBC & $479 \times 10^{4} / \mathrm{mm}^{3}$ & & HBs $-\mathrm{Ag}(-)$ \\
Plt & $15.6 \times 10^{4} / \mathrm{mm}^{3}$ & AFP & $273.7 \mathrm{ng} / \mathrm{ml}$ \\
T-Bil & $3.9 \mathrm{mg} / \mathrm{d}$ & CEA & $8.3 \mathrm{ng} / \mathrm{ml}$ \\
GOT & $1801 \mathrm{I} / 1$ & CA & $19-9$ & $2.0 \mathrm{IU} / \mathrm{ml}$ \\
GPT & $129 \mathrm{IU} / \mathrm{l}$ & & & \\
ALP & $1,026 \mathrm{IU} / 1$ & & & \\
AMY & $186 \mathrm{IU} / \mathrm{l}$ & & & \\
CRP & $0.1 \mathrm{mg} / \mathrm{dl}$ & & & \\
\hline
\end{tabular}



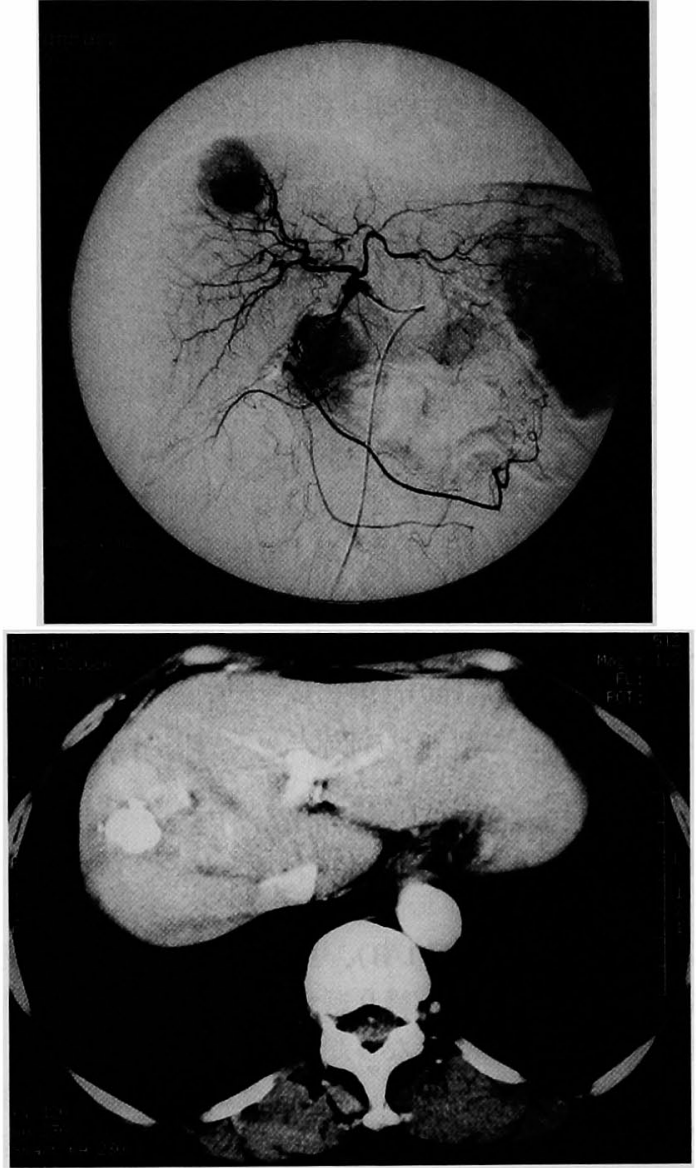

図 1 A 血管造影所見：肝 S 8 に約 $4 \mathrm{~cm}$ の hypervascular な腫瘤像を認め,門脈腫瘍塞栓は認めなかった。

B 2 回目の肝動脈塞栓療法後の腹部 CT 所見 : 肝 内胆管・総胆管の拡張は認めなかった。 $\frac{\mathrm{A}}{\mathrm{B}}$

ERCP：総胆管は最大径 $13 \mathrm{~mm}$ に拡張し，三管合流 部の直上にて総胆管の不整な閉塞を認めた。胆賈は造 影されており, 胆檉内に小結石と思われる透亮像が浮 遊していた（図 3 ）。

腹部 CT 検査：S 8 にリピオドールの集積した径 4 $\mathrm{cm}$ の腫瘤と肝内胆管の拡張を認めた（図 4).

以上より, 胆襄結石・肝細胞癌 - 閉塞性黄㾝の診断 にて1月18日開腹術を施行した。

手術所見 : 胆雓管を切離後, 胆道造影を行ったとこ ろ右肝管が閉塞しており (図 5 ), 総胆管を切開し胆道 内視鏡を挿入した，胆管内を観察すると右肝管に壊死 腫瘍と胆泥が充満しており，これらを胆道内視鏡より 挿入した鉗子を用い可及的に除去した.胆囊を摘出し，

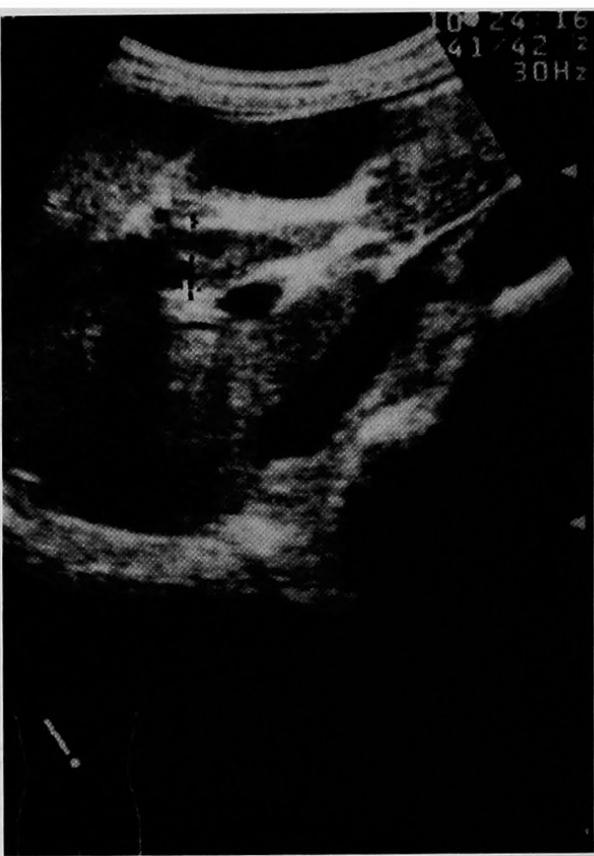

図 2 腹部超音波所見：拡張した胆管内に充実 性のエコー像を認めた。

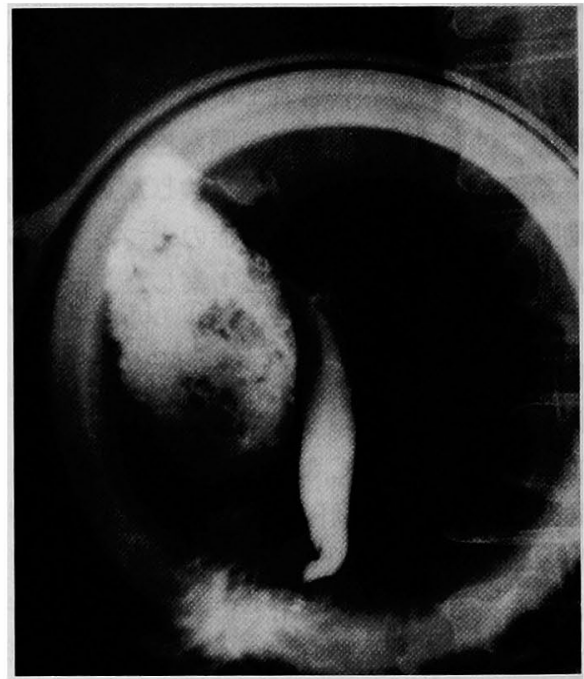

図 3 ERCP 所見：総胆管は拡張し, 三管合流 部の直上にて閉塞を認めた。

胆道再建術を施行した. S 8 の肝細胞癌は肉眼的にほ ほ壊死しており S 8 切除術を施行した.

摘出標本：胆管内に認められた腫湯栓は連続性は不 明であり約 $1 \times 6 \mathrm{~cm}$ の大きさで大部分は壊死してい 


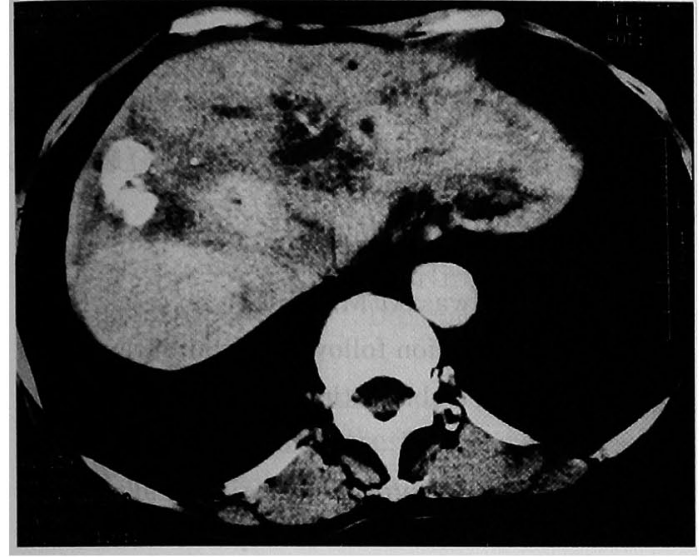

図 4 術前の腹部 CT 所見：肝内胆管の抎張を認めた。

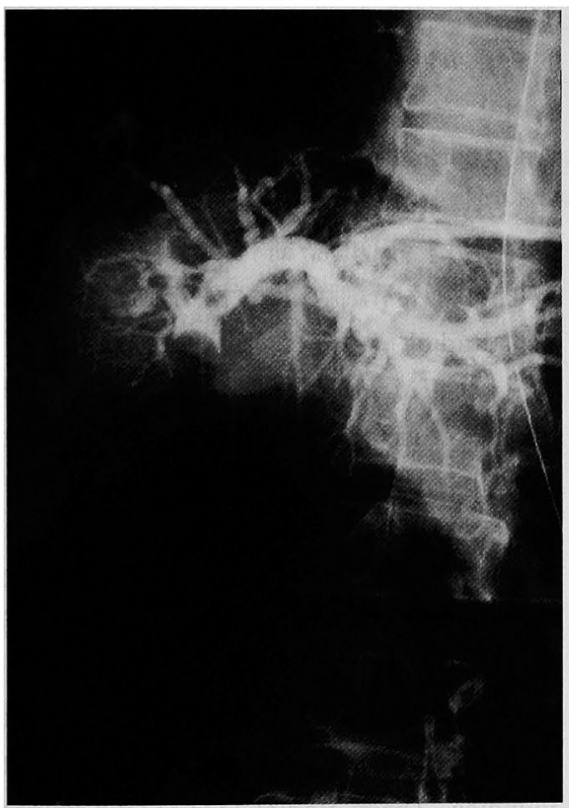

図 5 術中胆道造影所見：右肝管の閉塞を認 めた.

た(図 6 ). 肝切除標本の割面では肝細胞癌の近傍に腫 湟が充満した径 $5 \mathrm{~mm}$ の胆管を認めた。

病理所見：腫瘍栓は，ほとんどが買死組織で一部に て類円形核ないし不整形核を有し，クロマチン増量を 示す hepatocyte 類似の腫瑒細胞が主に索状の增生パ ターンを呈しておう，中分化肝細胞癌と診断され，肝 S 8 の腫瘍と同一の所見であった.また，腫崵周囲に胆 管壊死の所見が認められた。

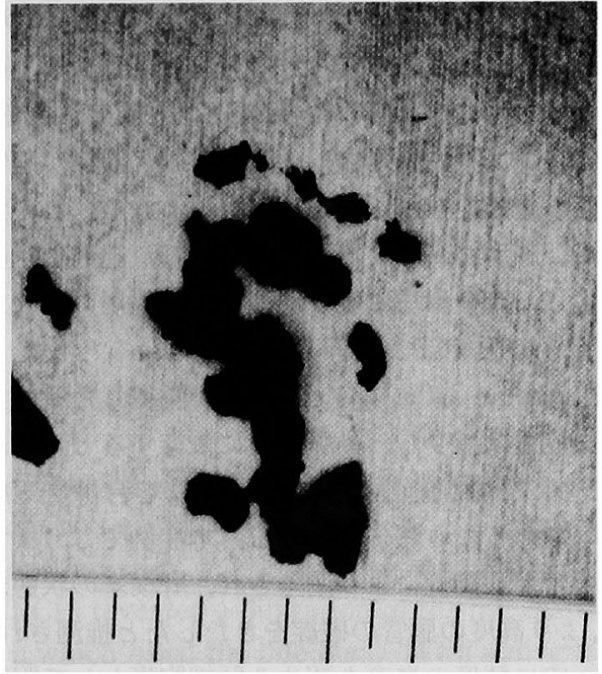

图 6 胆管内腫瘍栓標本肉眼像

考 察

肝動脈塞栓療法は肝細胞癌のみならず転移性肝腫場 に対しても有用であり確立された治療法であるが,

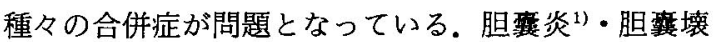
死 $^{2)}$ ・肝梗塞 ${ }^{3)}$ ・肝膿瘍4) ・胆管壊死 (5)などが報告されて いる，本例は肝動脈塞栓療法により胆管壁の壊死が引 き起こされ，胆管の破綻をきたし，さらに同部位より 壇死した肝細胞癌が胆管内に脱落し腫湯栓となったと 考えられた，胆管の壊死は報告されているが，腫場栓 は肝動脈塞栓療法の合併症としてきわめて稀であり, 本例に扔ける発症のメカニズムについて考察した。

肝動脈近位部がゲルフォームにて閉塞された場合で も側副血行路の発達により胆管壊死は通常発生しない とされるが, より末梢の肝動脈, さらには peribiliary arterial plexus が閉塞された場合は胆管の虚血も高度 になると考えられる. 本例でも 2 回目の塞栓療法は, 肝動脈前上枝より施行されており,初回の TACE に比 べより選択的に肝動脈の閉塞が行われていた.ゲルフ オーム細片による胆管壁の虚血性変化に加え肝亜区域 の梗塞性変化が胆管の破綻に大きく関与していると考 えられた.さらには，エピルビシンとりピオドールの 混和液を使用したために高濃度の抗癌郕が胆管壁にも 長期間にわたり停滞し，抗癌剂による組織障害により 胆管の壊死に大きく関与したと考えられた。

通常，末梢の胆管に㯖死が生じた場合，胆管壁の脱 落に伴い胆汁が肝内に貯留すると考えられる。このよ うな病熊は bile lake として塞栓療法の合併症として 
報告されている6!.また，これに感染を合併した場合 は，肝膿湯となると考えられる，本症例は末梢型の肝 細胞癌であり,末梢の胆管が壊死したと考えられるが, bile lake あるいは肝膿瑒は生じず, 壊死腫瘍が胆管内 に脱落し腫瘍栓を引き起こしたと思われる.この病態 として, 腫瘍がリピオドールに囲まれ, 腫瘍内圧の上 昇が生じ, 塞栓療法により壊死に宿り脆弱になった腫 陽が胆管の破綻部より押し出されたものと考えられ た. Doppman らわによると, 胆道が閉塞した状態では 門脈血流量は減少し, 動脈血流に依存するところが多 い゙ため, 肝動脈塞栓によって肝梗塞を合併する頻度 は高率であったと報告している，本症例でも，まず末 梢の胆管が腫瘍栓により閉塞され, 肝梗塞の状態が進 行し,より高度の胆管の破綻をきたしたと推測された.

胆管内に腫瘍の発育を認める肝細胞癌として胆管内 発育型肝紐胞癌が知られている. 胆管内に発育した腫 瘍そのもの，または腫瘍からの出血による凝血塊によ り胆管の閉塞をきたし黄㾝を生じると報告されてい る . 本症例においても壊死した腫瘍により総胆管の 閉塞をきたし黄㾝を認めたが，(1)肝細胞癌初発時より 2 回目の TACE施行時までのCTでは胆管に異常所 見を認めなかった. (2)病理所見にて胆管内に発育して いる肝細胞癌の所見が認められなかった。(3)肝細胞癌 の主腫瘍と腫瘍塞栓との連続性が認められなかった.

(4)腫堭周囲に胆管壊死の所見が認められた。以上の理 由により胆管内発育型肝細胞癌ではないと考えた。

臨床症状において, 黄㾝の自然消長が認められたが,

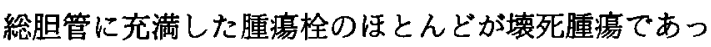
たためと考えられた。つまり総胆管に充満しているに もかかわらず, 腫瘍栓は脆弱であり胆汁の流出が可能 であったためと推測された。

手術方法として, 胆管空腸吻合も付加したが，これ は腫县栓の除去操作のみでは除去されない腫瘍栓が存 在する可能性があるために行った．肝細胞癌に対する 塞栓療法施行後に黄疸を認めた場合, 壊死腫瑒による 胆管腫瘍栓も合併症の 1 つとして念頭に置くことが必
要と思われた。

\section{結 語}

黄疸を伴った胆管腫癔栓の原因として肝動脈塞栓療 法による胆管の破綻が考えられた 1 例を経験したの で，若干の文献的考察を加え報告した。

文献

1) Kuroda C, Iwasaki M, Tanaka T, et al : Gallbladder infarction following hepatic transcatheter arterial embolization. Radiology 149 : 8589,1983

2) Nakamura $H$, Tanaka $T$, Hori $S$, et al : Transcatheter embolization of hepatocellular carcinoma; assessment of efficacy in cases of rescection following embolization. Radiology $147: 401-405,1983$

3) Kock NG, Hahnloser P:Interaction between portal venous and hepatic arterial blood flow: An experimental study in the dog. Surgery 72 : $414-419,1972$

4) 丸川太朗, 黒田知純, 細木拓野他: TAE 後に肝膿 瘍を合併した肝細胞癌の 3 例. 日血管造影. Intervent Radiol 研会誌 2:90-91，1987

5) Makuuchi M, Sukigara M, Mori T, et al : Bile duct necrosis; complication of transcatheter hepatic artery embolization. Radiology 156 : $331-334,1985$

6）芦澤和人, 松永尚文, 麻生暢哉他：肝動注塞栓療 法の合併症としての bile lake. 日医放線会誌 $51: 121-126,1991$

7) Doppman JL, Girton $M$ : The risk of hepatic embolization in the presence of obstructive jaundice. Diagn Radiol $143: 37-43,1982$

8）小西 大, 高安賢一, 森山紀之他：胆管内発育型 肝細胞癌 6 例の臨床放射線学的検討. 日消外会誌 $22: 2269-2274,1989$ 


\title{
A CASE OF HEPATOCELLULAR CARCINOMA WITH CHOLEDOCHAL OBSTRUCTION DUE TO TUMOR EMBOLUS AFTER TRANSCATHERTER ARTERIAL EMBOLIZATION
}

\author{
Tamotsu KUROKI, Yutaka KURODA, Wataru HONGO, \\ Kiyoshi NAKAYASU, Satoru KURATA, Sumihiko NAWATA, \\ Hiroshi NAGASHIMA and Kazuomi IWASAKI \\ Department of Surgery, Yamaguchi Prefectural Central Hospital
}

This paper presents a case of hepatocellular carcinoma with jaundice due to tumor embolus of the bile duct after transcatherter arterial embolization.

A 63-year-old woman who was followed for hepatitis $C$ was found having hepatocellular carcinoma in S8, and underwent transcatherter arterial embolization two times. Thereafter, the patient was admitted to the hospital because of right hypochondralgia and jaundice. CT scan, ultrasonography (US), and endoscopic retrograde cholangio-pancreatography (ERCP) revealed a dilatation of the intrahepatic bile duct, obstruction of the choledocus, and tumor embolus which filled the bile duct. With a diagnosis of obstructive jaundice, the patient was operated on when a necrosed tumor and bile sludge filling the bile duct were present. After removal of them, reconstruction of the biliary tract and a hepatectomy were performed. Histopathologically, the tumor embolus was mostly composed of necrosed tissues and was diagnosed as moderately differentiated hepatocellular carcinoma which was almost the same as the tumor of S8. The origin of the tumor embolus was thought to be necrosis and rhexis of the biliary wall due to transcatheter arterial embolization.

It is thought that we must entertain tumor embolus of the bile duct due to necrosed tumor as a probable complication of transcatherter arterial embolization. 